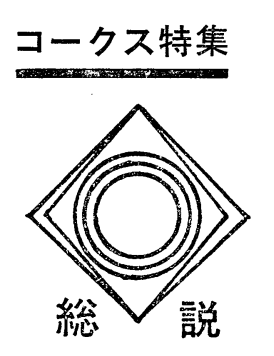

\section{コークスの高温性状}

\author{
-1979.10 .1 受理一
}

\section{1. 緒言}

コークスはその優れた高温特性のゆえに高炉の通気 性保持材や電極あるいはカーボン煟瓦などの原材料に 利用されているが，どのようなコークスでも工業的 使用に耐えうるかというと必ずしもとうでなく, 劣質 コークスを用いると高炉での棚吊り，スリップあるい は電極折損といったトラブルが頻発する。このような トラブルを解消するためにコークスの粒度分布, 回転 ドラム強度などに代表される常温性状が逐次改善され て来たが，最近になって高温性状の改善にも目が向け られるようになった。しかし,コークスは, 乾留直後の コークス塊一つを手にとって見ても，加熱壁に近い灰 白色の部分とそうでないより黒ずんだ部分に識別され るように非常に不均一であり亀裂もかなりコークス塊 内に存在し、 ニークスの性状を分析する上で非常に多 くの障害となる。例えば，熱伝導度の測定に龟裂のな いサンプルを取り出すのが困難であったり，具体例 そ挙げれば際限がないが，一番大きな問題点はコーク スの熱履歴の差がコークスの性質を著しく左右するた めに定量的論旨の展開が限定されることであろう。そ のため各物性值間の相互関係は, 測定データを多くと り単回帰あるいは重回帰分析を行なう段階にあり，系 統的な物性值間の関係を説明したものはないように思 う。そこで本稿では, コークスの物性值の温度依存性 に着目し，まずュークスの高温下での黒鉛化性に触 れ, ついで, その黒鉛化過程での物性変化を各項目毎 に述べると共に物性が影響を受ける因子について極力 言及するにとどめた。系統的な物性值間の相互関係は むしろ読者の推察にゆだねたい。

なお，高温下ではコークスとグラファイトの仕切り は困難であるが, コークスの黒鉛化が進み, 黒鉛の六角 形網目層を形成する $\sigma$ 電子の共有結合と層間結合を形

* 技術研究所 川崎市川崎区南渡田町1-1

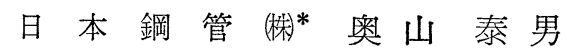

成する $\pi$ 電子の性格の相違からくる物性值の異方性が 顕著になるともはやコークスでなくグラファイトとい っても差しつかえないと解釈し，本稿ではコークスの 物性值についての方向性は配慮しなかった。また高温 性状といっても, その測定の多くは, 高温処理後冷却 したュークスの物性值であり，高温状態で測定してい るのは反応性, 回転ドラム強度, 収縮率などの報告が あるに過ざない。以上 2 点を予め断わっておきたい。

\section{2. 黒鉛化性}

コークスの乱層構造 (turbostratic system) は, 高 温で熱振動により発達し，石墨構造に移行するが，そ の黒鉛化工程の区分を本田 ${ }^{1)}$ は，磁気的性質から大き く 3 段階に分けている(図 1 参照)。

（1）半成石墨化 $\left(1000^{\circ} \mathrm{C} \sim 1400^{\circ} \mathrm{C}\right)$ 多環縮合環を中 心とした立体構造が瓌れ，次の縮合環形成反応が 起こる。

（2）石墨化 $\left(1400^{\circ} \mathrm{C} \sim 2300^{\circ} \mathrm{C}\right)$ 黑鉛化 2 次元格子の

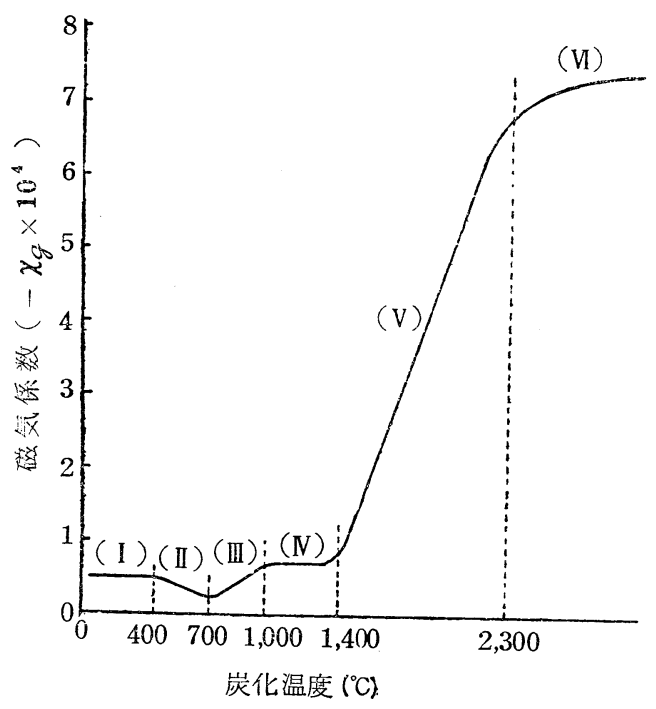

図 1 炭化温度による磁気係数 $\left(\boldsymbol{x}_{g}\right)$ の变化 
形成

（3）石墨結晶化 $\left(2300^{\circ} \mathrm{C} \sim 3000^{\circ} \mathrm{C}\right)$ 黒鉛化 2 次元格 子の再配列に上る石墨結晶の完成

しかし，どのコークスもこの分類にあてはまるのでは なく, 黒鉛化が進行し難いコークス (hard carbon) と 黒鉛化が容易なコークス(soft carbon) が存在する2)。 この黒鉛化性は，主にコークスの原料である石炭に左 右され，Goodarzi ら ${ }^{3)}$ は次のように石炭を分類して いる。

無煙炭 non graphitizing until a high temperature $\left(>2000^{\circ} \mathrm{C}\right)$

低揮発分潛青炭 potentially graphitizing

中揮発分瀝青炭 graphitizing

高揮発分瀝青炭 essentially non graphitizing また，原炭が不明でもコークスのX線回折で測定され る $\mathrm{a}$ 軸方向の結晶子の大きさ $\left(L_{\mathrm{a}}\right)$ と C 軸方向の結晶 子の大きさ $\left(L_{\mathrm{c}}\right)$ は有用であり， $L_{\mathrm{a}}$ と $L_{\mathrm{c}}$ を格子定数 で除した $L_{\mathrm{c}} / d_{\mathrm{c}}$ の関係から soft carbon か hard carbon かの区別が可能である。 hard carbon は, 一 般に $L_{\mathrm{a}}$ の増大に比し $L_{\mathrm{c}} / d_{\mathrm{c}}$ の成長が著しくない早。 その他, 原料石炭を酸化 ${ }^{4)}$ させたり乾留速度 ${ }^{4}$ を遅く したり、コークスになった後でも結晶化が進まない温 度での熱処理 ${ }^{5)}$ hard carbon の性格を強くする。 逆に $\mathrm{S}^{6)}, \mathrm{Ti}^{7}$ ), $\mathrm{Al}^{8)}$ などの存在は黒鉛化を促進する触 媒作用のために soft carbon に近づく。なお， $L_{\mathrm{a}} ， L_{\mathrm{c}}$ は，温度依存性が高く，所定の温度にコークースを保

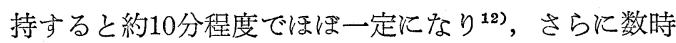
間保持してもその増加は僅かである ${ }^{13)}$ 。そのため $L_{\mathrm{a}}$ ， $L_{\mathrm{c}}$ はコークスの黒鉛化度を定量的に示すパラメータと してよく用いられている。soft carbon では， $L_{\mathrm{c}}$ は1000 ${ }^{\circ} \mathrm{C}$ 以上で著しい発達を示すが10)， $L_{\mathrm{a}}$ は, 水素ガスを主 成分とする揮発分が出る $1500^{\circ} \mathrm{C}$ 程度まで悇々に成長 し, $2000^{\circ} \mathrm{C}$ を越えるととの成長速度が速く $100 \AA$ 以上に なり(いわゆる黒鉛化 2 次元構造の段階)， $3000^{\circ} \mathrm{C}$ 付近 では数千 $\AA$ にるなる11)。方筧hard carbon では, 2000 ${ }^{\circ} \mathrm{C}$ 以上になると，3次元構造の発達を阻止していた炭

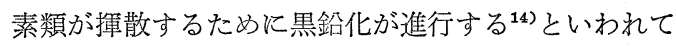
いるが，局部的にしか進行せず，いわゆる multiphase graphitization の形で進行するという説 ${ }^{15)}$ パラメータ がある。圧力は黒鉛化を著しく促進させ $5 \mathrm{kbar}$ 圧力 下では $1500^{\circ} \mathrm{C}^{17)}$ で, $15 \mathrm{k}$ bar では $1000^{\circ} \mathrm{C}$ で黒鉛化が起 こる18) と報告されており， hard carbon を熱処理する 子熱歪で集中的に压力がかかった気孔の周团だけが 選択的に黒鉛化ぶ進えだりする multi-phase 説が妥当であろう。また，コークスの黒
鉛化度が進み, $L_{\mathrm{a}}$ が $110 \AA$ 以上になった場合の黒鉛化 度のパラメータとして相重さなる層面が黒鉛の配列を する確率 $P$ 方提案されている。

$$
\begin{aligned}
& d=3.440-0.086\left[1-(1-P)^{2}\right] \\
& P=1-110 / L_{\mathrm{a}} \\
& d=3.354 P+3.44(1-P)
\end{aligned}
$$

但し， $L_{\mathrm{a}}<100 \AA$ では $P=0, d$ は層面間隔

\section{3. 化学的性質之電気磁気的性質}

コークスを加熱して行くと，吸着されているガスが 脱着されてくる。この吸着ガスは，コークスを空気中 に放置したときに表面炭素に吸着された酸素などであ り,コークスを $1000^{\circ} \mathrm{C}$ 以上で長時間真空加熱しなけれ ば完全にはとれず21)，一部化学吸着に近い状態の酸素 もあると考兄られよう。例えば，単に乾燥しただけの 特別な予備処理をしないコークス粉を $925^{\circ} \mathrm{C}$ に加熱す ると $\mathrm{CO} 36.1 \%, \mathrm{~N}_{2} 17.9 \%, \mathrm{H}_{2} 31.1 \%, \mathrm{CO}_{2} 12.4 \%$ の組成のガスが発生した報告 ${ }^{22}$ がある。また極端な例 として, 活性炭は $1000^{\circ} \mathrm{C} て ゙ 10$ 時間加熱しても COの 発 生が止まない ${ }^{23)}$ 。吸着ガスの脱離現象に影響を与える 因子として, 熱処理温度と時間の他に灰分と粒度が主 なものとして挙げられており, 粒度が細かい程脱着が ス中の $\mathrm{CO}_{2}$ 含有量が高く, 灰分の増加は $\mathrm{CO}$ の脱離 を妨げるようである24。ささらにコークスを高温に加熱 していくと，灰分の減少，へテロ原子 ( S, N , P ) の 減少が観察される。図2 亿灰分, 硫黄, 窒素の熱処理に よる減少の一例を示した ${ }^{83)}$ 。灰分はその組成によって 減少傾向が異なるのは当然であるが，硫黄について見 ると, コークス中の硫黄の存在形態は, (1)硫化鉄(2)有 機硫黄(3)遊離硫黄の 3 つが考えられている25)。この中 で最も脱硫され易いのが硫化物で $1300^{\circ} \mathrm{C}$ 亿加熱すると

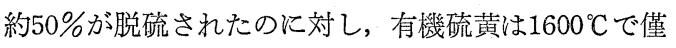
か20\%程度しか脱硫されない例がある゙ 。遊離硫黄 は, 本来含有量が $0.1 \%$ 程度と低いので分析精度に問

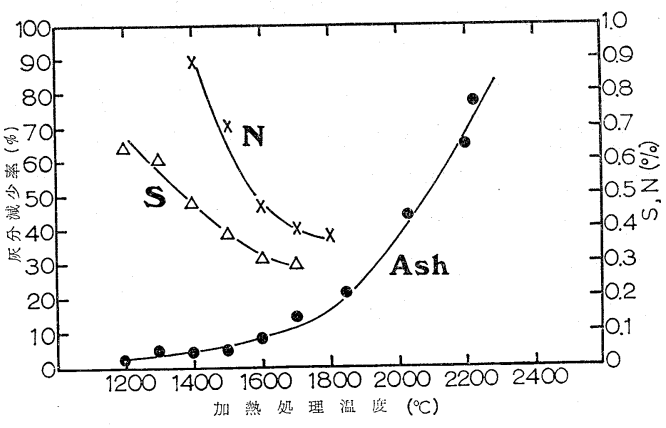

図 2 熱処理によるコークスの脱灰, 脱 $\mathbf{S}$, 脱 $\mathbf{N}$ 
題があるが $1600^{\circ} \mathrm{C} て ゙ 50 \%$ 程度は除去されるようであ $る^{28)}$ 。従って脱硫の温度依存性は, コークス中の硫黄 の形態別含有量によって異なりあるコークスでは， $1300^{\circ} \mathrm{C}$ 以上で急激な脱硫そ示し ${ }^{27)}, 1400 \sim 1500^{\circ} \mathrm{C}$ で急 激な脱硫を示すコークス ${ }^{28)}$ する。その他，脱硫黄を 影響する因子に䨌囲気がある。水素雾囲気は脱硫を促 進すること敉は上く知られているが， $\mathrm{CO}_{2}$ 雲囲気下で 脱硫が生じないのは, Boudouard 反応に上り生ずる $\mathrm{CO}$ が(4)式の反応を阻害し ${ }^{27)}$, 生成した $\mathrm{CO}_{2}$ とコーク スの反応る併行するので著しいカーボンロスを招くた めであると推察されている ${ }^{30)}$

$$
\mathrm{C}_{x} \mathrm{~S}_{y}+\mathrm{CO}_{2} \rightarrow \mathrm{ZCO}+\mathrm{SO}_{z}+\mathrm{S}+(\mathrm{X}-\mathrm{Z}) \mathrm{C}
$$

$\mathrm{H}_{2}, \mathrm{H}_{2} \mathrm{O}$ 雾囲気や不活性䨌囲気での脱硫黄速度は, 二 一クス粒径に反比例するが，1時間も保持するとほほ 平衡值に達している ${ }^{30)}$ 。

コークス中の窒素は，0.4 1.5\%を占めるが，その 存在形態は明らかにされてない。コークス中の窒素を 定量する方法に乾式法と湿式法があり，その分析值の 差は瀝青炭コークスにのみ認められることから，瀝青 炭コークスには湿式法では $\mathrm{NH}_{3}$ になり難い複素環式 $\mathrm{N}$ 化合物が $20 \sim 30 \%$ 存在すると考兄られている ${ }^{31}$ 。高 温にすると硫黄同様脱窒素が起こり, 保持温度に打け る平衡窒素量が存在している ${ }^{25)}$ 。1 $800 \sim 1900^{\circ} \mathrm{C}$ で $87 \%$ 25), $1700^{\circ} \mathrm{C}$ では約 $75 \%$ の脱窒素率で硫黄の $1700^{\circ} \mathrm{C}$ 約 $50 \%$ 脱硫率よりも高い值を示した例 32 がある。P ついて子高温にすると除去され，所定温度に 1 時間保 持するとほほ平衡リン含有量になっている ${ }^{35}$ 。減圧下 $\left(10^{-2} \mathrm{mmHg}\right)$ では,ょり早く平衡值に達するだけで平衡 值そのものはあまり変わっていない25)。コークスの種 類による脱 $\mathrm{P} へ$ 影響は, 高揮発分の石炭を原料にし たコークス程低い脱 $\mathrm{P}$ 率を与兄る傾向があるようであ $ろ^{35)}$ 。水素も当然高温になると低下するが，未処理コ 一クスで $0.63 \%$ の值が $1400^{\circ} \mathrm{C}$ 加熱で $0.43 \%$ に低下した 例がある 題があらう。

\section{(ラジカル濃度)}

高温状態のコークス中のラジカル濃度を測定する技 術はまだなく，高温処理したコークスの室温での電子 スピン共鳴 (ESR) スペクトルからいくつか前提条件 を設定した上でラジカル濃度を測定している ${ }^{37) 。 し か ~}$ し，1000畐以上に熱処理されたコークスの ESR シグ ナルについては, フリーラジカルか伝導電子によるか などの議論もあり明白な結論は得られてないためにラ ジカル濃度は求められていない行。四 3 亿石炭を原料 にしたコークスのスピンセンター濃度を示すが， 1400

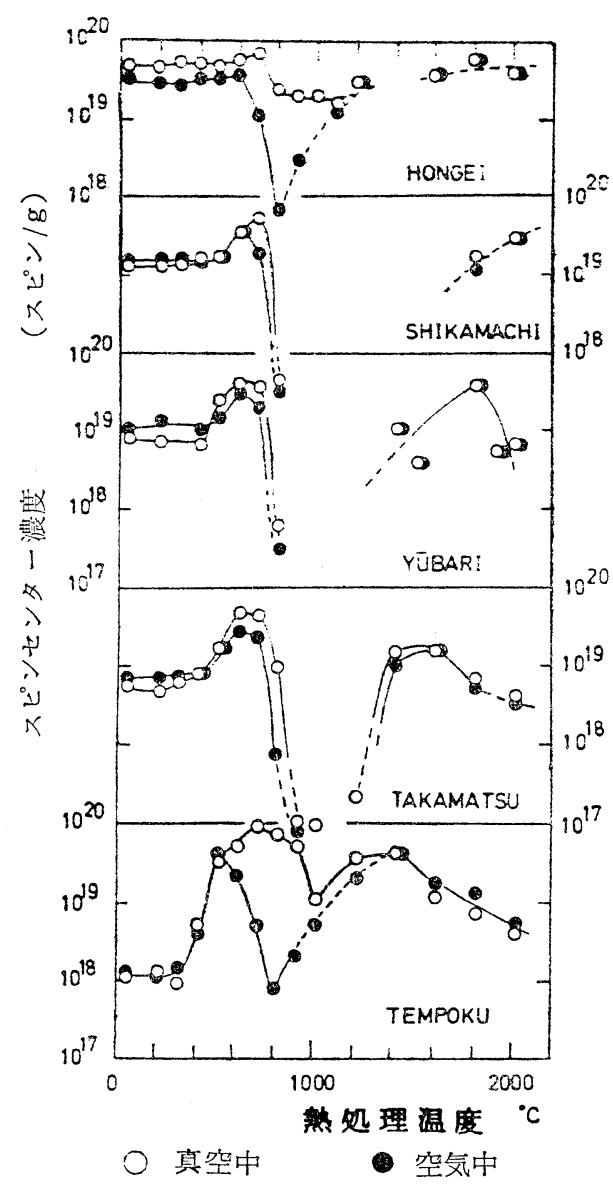

\section{図 3 炭化過程における ESR から求めた スピン濃度}

${ }^{\circ} \mathrm{C}$ 以上の高温域にみられるピークが存在する理由につ いて次のように推察されている37)。コークスは, 1000 ${ }^{\circ} \mathrm{C}$ 付近から 3 次元架橋構造から 2 次元石墨様構造に移 行するため, 立体結合が切れ新しいスピンセンターが 生じる。しかし， $1400^{\circ} \mathrm{C}$ 以上になると芳香族核がある 程度大きくなるために非局在型スピンセンターになり 石畦構造の発達と共にスピンセンター濃度が減少し, $3000{ }^{\circ} \mathrm{C}$ 付近では黒鉛と同じスピンセンター濃度 ( $5 \times$ $10^{8}$ スピン/g)によでなるためであろうという説であ る。また，ピッチコークスのスピンセンタ一檂度は， 石炭コークスのそれと異なり, 低濃度で高温になるに 従い低下の一途をたどっている37)。このスピンセンタ 一濃度の羑と化学反応律速の領域でのコークスの $\mathrm{CO}_{2}$ 反応性と結びつけようという試みがあるが ${ }^{38)}$, 石炭コ 一クスの灰分の影響を除くのが困難であろう。ゲお, セミコークスのラジカル 濃度については, ESR だけ でなく前述の磁気係数 $\left(X_{\mathrm{g}}\right)$ からキュリーの法則に 
より $X_{\mathrm{g}}-1 / T$ の関係をプロットし, 反磁化率 $\left(X_{\mathrm{dia}}\right)$ を求め $\left(X_{\mathrm{g}}-X_{\mathrm{dia}}\right)$ を用いてフリーラジカルの磁化率 を $1250 \times 10^{-6} \mathrm{emu} / \mathrm{mol}$ と仮定して求める方法が紹介 されており ${ }^{39)}, \mathrm{ESR}$ から求めたラジカル濃度と傾向は 類似している。この手法は高温処理コークスへの適用 も考光られると思うがいかがであろうか。

\section{(レーザーラマン)}

この手法はまだ歷史が浅く、コークス類に適用され たのは 1970 年である ${ }^{40) 。 コ ー ク ス の ラ マ ン ハ ゙ ン ト ゙ は ~}$ $1580 \mathrm{~cm}^{-1}$ と $1360 \mathrm{~cm}^{-1}$ の 2 つのピークが観察され, $1580 \mathrm{~cm}^{-1}$ は黑鉛の六角網目状構造に起因し $1360 \mathrm{~cm}^{-1}$ の方は多結晶構造によるといわれている(1)。このピー ク比 $\left(\mathrm{I}_{1360} / \mathrm{I}_{1880}\right)$ は, 結晶化度のパラメータとして用 いられ，X線で求めた $L_{\mathrm{a}}{ }^{41)}$ や有効 Debye パラメータ (Beff $)^{42)}$ と高度の相関が認められている。今後コーク スのキャラクタリゼーションに活用されよう。

(電気抵抗)

ニークスの電気抵抗が負の温度係数をもつことは上 く知られているが，コークスの熱処理温度が高くなり 黒鉛化が進むと金属型に移行し，電気抵抗は小さくな り，黒鉛の電気抵抗は正の温度係数を示している（図 4 参照 $)^{13)}$ 。例えば $2600^{\circ} \mathrm{C}$ 熱処理の石油コークスは，中 間的性質を呈し, 約 $500^{\circ} \mathrm{C}$ 以下では負, それょり高 温では正の温度係数を示している(3)。コークス塊の電 気抵抗の測定には, サンプルと電極端子との接触抵抗 の補正が課題であるが，コークス塊や粉の充填層の電 気抵抗を高温で測定した方がより実用的な場 合があ る。コークス塊の場合 $1400^{\circ} \mathrm{C}$ 付近に小さな極大值を認

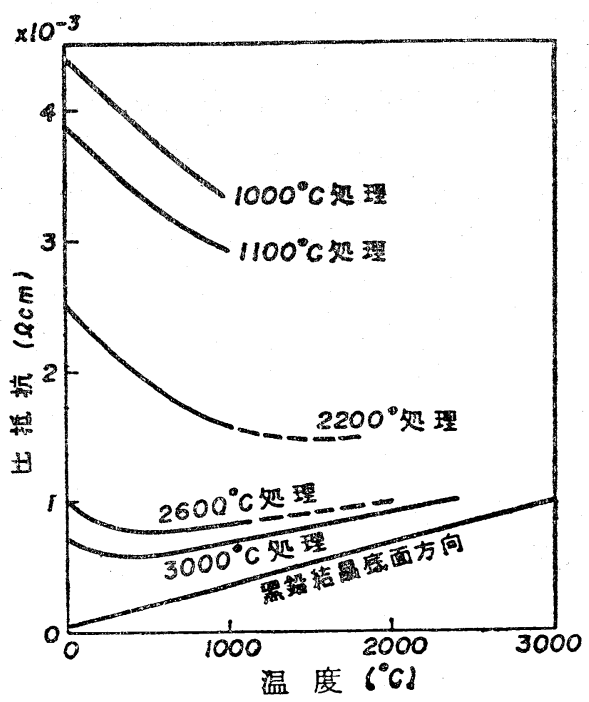

図 4 コークス類の電気抵坑の温度依存性
めた例があるようであるが出，粉コークスの場合は電 気抵抗は温度と共に小さくなるが $1100^{\circ} \mathrm{C}$ 付近に屈曲点 が観察されており $1500^{\circ} \mathrm{C}$ 以上では電気抵抗はほとんど 変わらなくなっている45)。また高流動度の石炭ほど電 気抵抗の小さいコークスを生成する(6) ことは興味深 w。

\section{（反応性）}

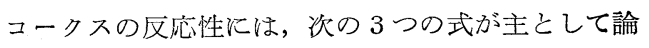
じられている。さらに対象を高炉に限定すると，

$$
\begin{aligned}
& \mathrm{C}+\mathrm{O}_{2} \longrightarrow \mathrm{CO}_{2} \\
& \mathrm{C}+\mathrm{H}_{2} \mathrm{O} \longrightarrow \mathrm{H}_{2}+\mathrm{CO} \\
& \mathrm{C}+\mathrm{CO}_{2} \longrightarrow 2 \mathrm{CO}
\end{aligned}
$$

羽口先と $900 \sim 1300^{\circ} \mathrm{C}$ のシャフト部で主に進行してい る ${ }^{122)}$ と考えられるソリューションロス反応 $((6)$ と(7)) と羽口先での $1600^{\circ} \mathrm{C}$ 以上で起こると考兄られる燃焼 123) ((5)) が問題になっている。な掞りリューションロ ス反応のうち, 量的には(7)式の Boudouard 反応の方 が多く，ともすれば，(6)式の水性ガス反応は等閑視さ れがちであった。

(i) 然焼について

高炉の羽口先でのコークスの挙動を見るためにコー クスの然焼装置が作られているが118)119)，それによる と, コークス基質の反応性よりも, コークスの粒度分 布の方が燃焼挙動に大きな影響を与えていることが推

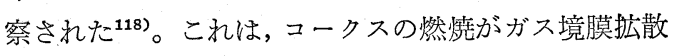
律速で進行していることを示唆して扣り, 実験室的に

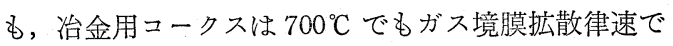
あることが空気酸化反応に扮いて確かめられている 47)。またコークス以外でも，ブラッシューカーボンは $800^{\circ} \mathrm{C}^{48)}$, グラファイト小球は $850^{\circ} \mathrm{C}^{49}$ 高純度グラファ イトでは $1200^{\circ} \mathrm{C}^{50)}$ 以上でガス境膜拡散律速であること が確認されている。区応速度定数については, 図 5 に 示すように種々のコークスについて広範囲の温度にわ たる平均的な式(8)が求められている51)。

$$
K=3050 \exp (-179.4 / R T)
$$

高純度カーボンの活性化エネルギーは $290 \mathrm{KJ} / \mathrm{mol}$ と 高く活性に富むコークスでは $126 \mathrm{KJ} / \mathrm{mol}$ という値の 範囲内に全てのコークスが含まれているようである。 また燃焼の反応速度式は $N_{\mathrm{sh}}=f\left(N_{\mathrm{Re}}, N_{\mathrm{sc}}\right)$ の経験 式をべースにしたものが用いられている ${ }^{49)} 。$

(ii) ソリューションロス反応について

先にも述べたようにソリューションロス反応のうち Boudouard 反応の影響の方が水性ガス区応上りも大 きいという考方方から Boudouard 反応に関するもの が非常に多い。、しかも, Boudouard 反応は, 1100 C以 


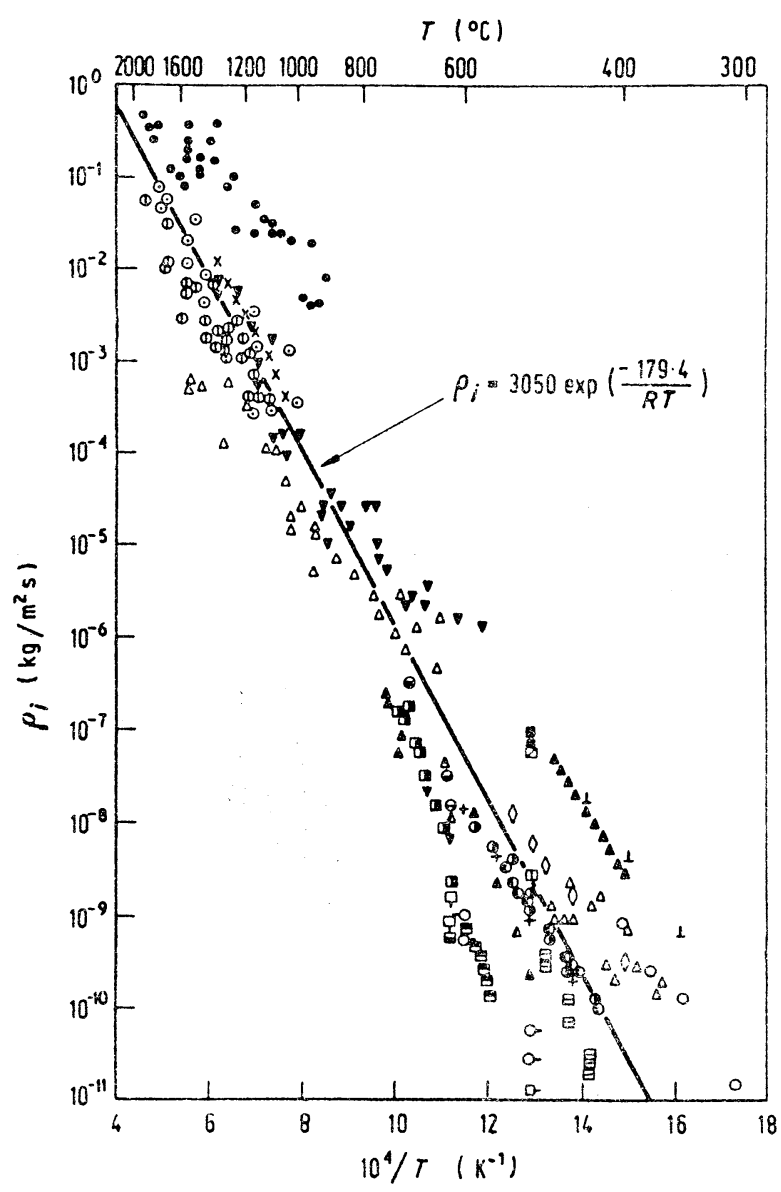

図 5 酸素分圧 $101 \mathrm{kpa}$ におけるコークス類の反応速度

下が化学反応律速であり, $1100^{\circ} \mathrm{C} \sim 1500^{\circ} \mathrm{C}$ で気孔内払 散律速, $1500{ }^{\circ} \mathrm{C}$ 以上がガス境膜拡散律速であるといわ れている ${ }^{73)}$ ためか，羽口先での $1600^{\circ} \mathrm{C}$ 以上の Boudouard 反応関するものは少ない。図 $6^{75)}$ にとの一例を 示すが灰分のないグラファイトの $\mathrm{CO}_{2}$ 反応性は $1700^{\circ} \mathrm{C}$ $\sim 1800^{\circ} \mathrm{C}$ 付近に反応速度の極大值を示し, 気孔に $\mathrm{Si}$ を埋込んだグラファイトには極大值はなくなってい る。このように灰分を除去し不活性になったカーポン の場合は, $1600^{\circ} \mathrm{C}$ 以上でもガス境膜拡散律速とは言い 難い現象を示している。Ash less コークスのメリット を示唆しているのではないだろうか。一方 $900 〜 1300^{\circ} \mathrm{C}$ 領域での Boudouard 反応に関するものは数多く報告 されている。コークスの気孔率52)や，内部表面積53)が 大きいと反応性は高くなり，(気孔壁の厚さ／気孔径） 54)が大きいと逆に反応性は低くなるといった頻度因子 に関連するものや結晶化度が進むと反応性が小さくな $\eta^{59)}$, コークス灰分 ${ }^{(8)}$ 打よびアルカリ，アルカリ土類

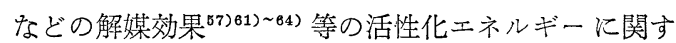
るものがある。また両方に関連したものに, ニークス の熱処理温度を上げていくと， $1700^{\circ} \mathrm{C}$ をで内部表面 積の減少, 結晶化度の進行により反応性は低くなる が， $1700^{\circ} \mathrm{C}$ 以上になると，コークス灰分が還元され， 触媒作用が顕著になり反応性は増加する例がある。そ の他，コークス組織による反応性を識別する方法があ $\eta^{55)}$ ，等方性組織 ${ }^{56)}$ やイナート質 ${ }^{60)}$ の反応性は高く， 光学的異方性が進むにつれて反応性は低くなるようで ある。コークス組織から反応性を論じる場合は、コー クス組織は $1000^{\circ} \mathrm{C}$ 以上では発達しないために, 熱処理 温度による活性化エネルギーの変化を考慮する必要が あり， $L_{\mathrm{c}}$ やコークスの平均最大反射率 $\bar{R}_{\max }$ 等で補 正しなければならない。反応速度式については，Langmuir-Hinschelwood 型のものが大部分であるが, 次 の 6 式が主なものである。これらの速度式の詳細な比 較検討がなされているが121)，一般に Gasby らの(13)式 

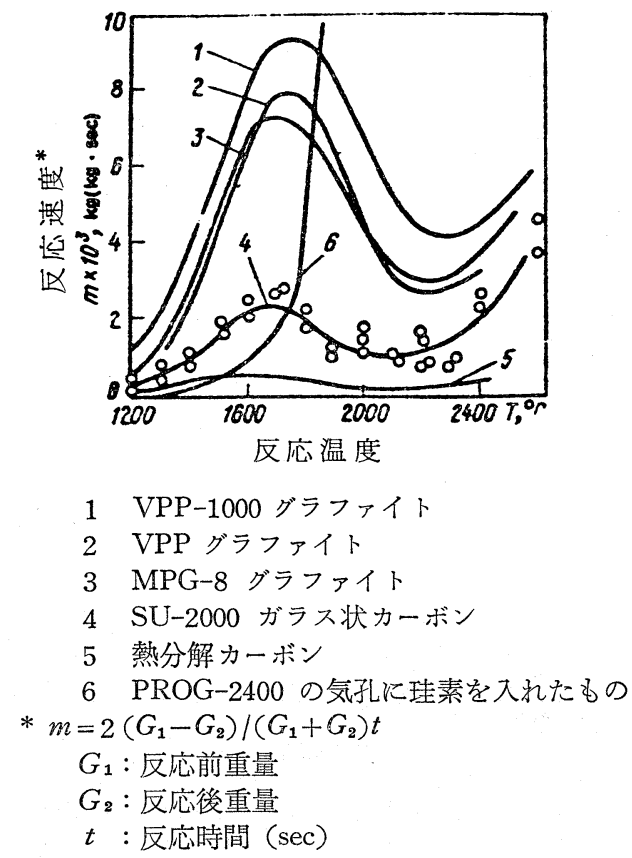

图 6 各種カーボンの反応性と反応温度 (䨌囲気 $\mathrm{CO}_{2} 23 \%$, Ar. $77 \%$ )

がパラメータ数も多く, データを精度よく表わすため によく用いられている。

$$
\begin{array}{rlr}
R= & k_{1}\left(P_{\mathrm{CO} 2}-P_{\mathrm{CO} 2}, e\right) /\left(1+k_{2} P_{\mathrm{CO}}\right) & (9)^{65)} \\
R= & k_{1} /\left[1+\left(P_{\mathrm{CO}} / P_{\mathrm{CO} 2}\right) / k_{2}\right] & \left(10^{66}\right) \\
R= & k_{1}\left(P_{\mathrm{CO} 2} / P_{\mathrm{CO}}\right) /\left[1+k_{2}\left(P_{\mathrm{CO} 2} / \mathrm{P}_{\mathrm{CO}}\right)\right] & (11)^{67)} \\
R= & k_{1}\left(P_{\mathrm{CO} 2} / P_{\mathrm{CO}}-P_{\mathrm{CO}} / K_{B}\right)+ & \\
& k_{2}\left(P_{\mathrm{CO} 2}-P^{2} \mathrm{CO} / K_{B}\right) & (12)^{68} \\
R= & k_{1} P_{\mathrm{CO} 2} /\left(1+k_{2} P_{\mathrm{CO}}+k_{3} P_{\mathrm{CO} 2}\right) & (13)^{(6)} \\
R= & k_{1} P_{\mathrm{CO} 2} /\left(1+k_{2} \sqrt{P_{\mathrm{CO}}}+k_{3} P_{\mathrm{CO}_{2}}\right. & (14)^{70)}
\end{array}
$$

但し, $k_{1}, k_{2}, k_{3}$ は定数, $P_{\mathrm{CO}_{2}}, e, K_{B}$ は Boudouard 反応の平衡分圧および平衡定数, $P_{\mathrm{CO}}, P_{\mathrm{CO} 2}$ は $\mathrm{CO}$, $\mathrm{CO}_{2}$ の分圧。

$\mathrm{CO}_{2}$ のコークス粒子内有效拡散係数 $\left(D_{\mathrm{e}}\right)^{71)}$ やコー クス粒径 ${ }^{22}$ の補正項を入えた反応速度式も提案されて いる。さらに, 水性ガス反応を考慮したものとして, (13)式についてい光涪, $k_{4} P_{\mathrm{H} 2 \mathrm{O}}$ が分子に $k_{5} P_{\mathrm{H} 2 \mathrm{O}}$ が分目 に加えられている76)。水素の影響については, コーク スと化学吸着する説もあり十分に解明されていない。 例えば, $\mathrm{H}_{2} \mathrm{O}-\mathrm{N}_{2}$ 系と $\mathrm{H}_{2} \mathrm{O}-\mathrm{H}_{2}$ 系のコークスのガス化 反応速度に浪差が ないという $\mathrm{H}_{2}$ 無害説 ${ }^{6)}$ と， $\mathrm{CO}-$ $\mathrm{CO}_{2}$ 系に $\mathrm{H}_{2}$ を添加するとコークスの反応速度が増す という促進説 ${ }^{77)}$ と $\mathrm{CO}_{2}-\mathrm{H}_{2}$ 系の反応では速度が途くな るという阻害説 ${ }^{78)}$ がある。コークスと反応する直前の ガス組成を正確に測定する実験技術がこれを解明する
決め手となろう。

\section{4. 物理的性質}

コークスを高温に曝すとマクロ的には，収縮による 亀裂が随所に発生し，ミクロ的には超微細亀裂が融着 し，内部表面積は小さくなり、コークス壁の強度も低 下すると言われている。このようなコークスの熱的劣 化をコークス塊の性状変化として測定することは，安 定な工業生産を確保するための必須条件の一つであ る。

\section{（収 縮）}

コークスを加熱していくと，乾留温度以下では膨脹 するかも知れないが，それ以上の温度では収縮する (図 7 参照 $)^{79)}$ 。この収縮量の温度依存性は高く, 所定 の温度に 4 時間も保持すると収縮はとまる。これより アレニウスプロットにより収縮の活性化エネルギーを 求めた例がいくつかあり, $33 \mathrm{kcal} / \mathrm{mol}(1700 \sim 2900$ $\left.{ }^{\circ} \mathrm{C}\right)^{80)}$ から $268 \mathrm{kcal} / \mathrm{mol}\left(1860 \sim 2500^{\circ} \mathrm{C}\right)^{81)}$ の間市る ようである。収縮現象をミク口的に見ると格子定数の 低下であり，マクロ的には，ミク口的収縮の単純な和

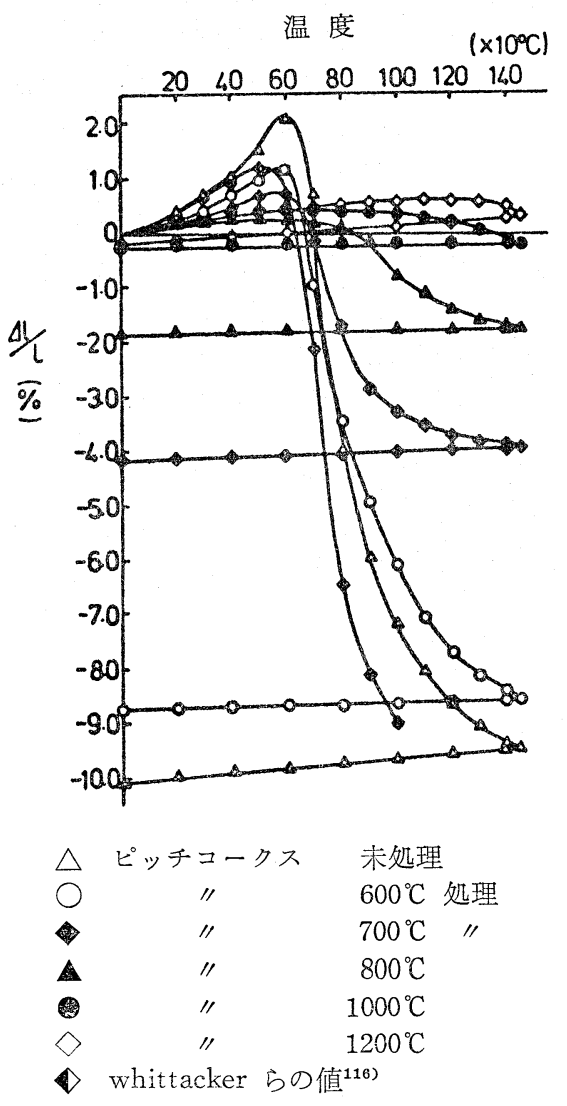

図 7 各榰ピッチコークスの膨脹一收縮曲線 
ではなく, soft carbon の比率や気孔の数とその大き さなどが影響し合ったものとして観察されると推察さ れている82)。

\section{(顕微鏡観察)}

コークスを顕微鏡観察する場合, コークスの光学的 異方性を忘れてはならない。1945年に Marshall83) が 紹介して以来多くの研究がなされているが，コークス の光学的異方性の模様（モザイク状とか繊維状）の発 達は $1000^{\circ} \mathrm{C}$ 以下に限定され, 乾留中の加熱速度を大に したり，保持時間を長くするとその異方性が進展する ことが確認されている84)。しかし，コークスになって しまうと, 異方性模様の発達はグラファイトにならな い限りあり得ないようで ${ }^{85)}$, 例光ば, $2500^{\circ} \mathrm{C}$ 亿長時間保 持しておくと, soft carbon の部分がグラファイト状 の異方性模様に変わっている ${ }^{88)}$ 。ところが, hard carbon の一例として, $5 \mathrm{k}$ bar の高圧下で $2000^{\circ} \mathrm{C}$ 処理し てもグラファイト状にならず，元の光学的異方性模様

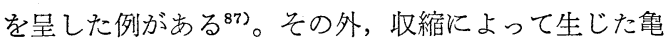
裂も観察される。龟裂は，特䇛維状組織に入りやす く，その積層方向に平行に凸レンズ状に発生するのが 通例であるようである ${ }^{88)}$ 。熱処理したメソカーボンマ イクロビーズを走査型電子顕微鏡 (SEM)で見ると， その積層方向之平行に走る急裂が観察される ${ }^{899}$ 。この ように収縮によって発生したマク口角裂は, 処理温度 が高くなる程増加するのに反し，微細亀裂はあたかる 融着したかのように見えなくなってしまうようである 90)。また， $\mathrm{CO}_{2}$ や $\mathrm{O}_{2}$ と反応したコークスを $\mathrm{S} \mathrm{EMで}$ 観察し, 触媒が存在する部分に空洞が発生し、 コーク スの粉化，龟裂の発生源となることなどが判明してい $3^{88)}$ 。

\section{（内部表面積）}

コークスの反応性とも関連し，重要な性質の一つで あるが，その測定には $\mathrm{CO}_{2}$ 吸着による Dubinin-Polanyi の式を用いる方法が今のところ最も正確とされ ているようである ${ }^{91)}$ 。 $\mathrm{N}_{2}$ 吸着は吸着速度が遅いだけ でなく, その有效分子径が $\mathrm{CO}_{2}$ よりも大きいことが証 明されている。モレキュラーシーブ $5 \mathrm{~A}$ の此表面積は， $770 \mathrm{~m}^{2} / \mathrm{g}\left(\mathrm{N}_{2}\right)$, と $695 \mathrm{~m}^{2} / \mathrm{g}\left(\mathrm{CO}_{2}\right)$ であるのに対し, モ レキュラーシーブ $4 \mathrm{~A}$ の比表面積は, $1 \mathrm{~m}^{2} / \mathrm{g}\left(\mathrm{N}_{2}\right)$ と $610 \mathrm{~m}^{2} / \mathrm{g}\left(\mathrm{CO}_{2}\right)$ の值がそれを如実菞語っている ${ }^{92)}$ 。 メタノールはその極性のために不適当とされ，クリプ トンやキセノンが提案されているが93)，その装置が高 圧であるという煩しさから普及してない。コークスの 比表面積は，処理温度が高くなるにつれて減少の一途

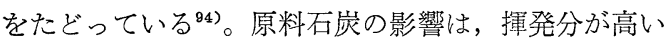

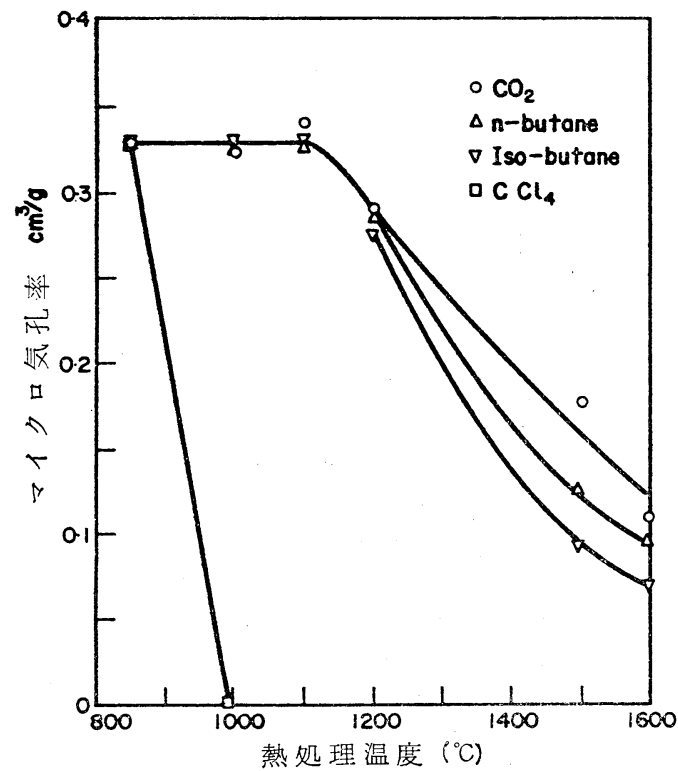

図 8 処理温度によるマイクロ気孔の变化

ほど高い比表面積のコークスが生成している。図８に 活性炭についての表面積から求めた微細気孔率の変 化を示すが95)，高炉解体コークスの比表面積もソリュ ーションロス反応で增大した後, 羽ロレベルに近ゔ くに従い急激に低下していることが報告されている 120)。

\section{（反射率）}

コークスの平均最大反射率 $\left(\bar{R}_{\max }\right)$ は, 処理温度に より大きく変動し，1200～ $1500^{\circ} \mathrm{C}$ 亿極大值を示すよう である ${ }^{98)}$ 。この処理温度の影響に比し, 原料石炭の影 響は非常に小さい(4)ために $\bar{R}_{\max }$ は $L_{\mathrm{c}}$ ほど正確では ないが，コークスの熱処理温度を知る一つの目安にな ろう。また，炭化過程で局部的に圧力が発生し異方性 が増す例が紹介されている。通常コークスの $\bar{R}_{\max }$ と $\bar{R}_{\min }$ は, 炭化過程で㴗梁正比例している ${ }^{97)}$ が, 局部 的圧力が存在すると， $\bar{R}_{\max }+\bar{R}_{\min }=$ 一定の関係を保 ちながら $\bar{R}_{\max }$ が增大するというのである ${ }^{98)}$

(基質強度)

コークスの機械的強度を表示するのに，回転ドラム 型式の強度試験が日本だけでなく世界各国で企業べー スで用いられている。しかし，ドラム試験によって求 められたドラム指数は，コークスの機械的強度の代用 特性值に他ならず, 物性值としての真值は存在しな い。従ってコークスを高温処理することによって著し く低いドラム指数が得られた場合に, 具体的に何を改 善すればよいのか明らかにする必要がある。いま，コ 
ークスを多孔質材料と認識し、コークスの壁の部分の 硬度やャング率, さらには気孔率や気孔の形・大きさ の影響を加味した引張り強度とか曲げ強度といった真 值があるものを基質強度と考えると，ドラム指数は， 基質強度やコークス塊内の嶑裂の度合, コークス粒径 と形状等の関数として表わせるのではないかと定性的 に読者に理解されよう。こういった観点から, 高温下 でのコークスの基質強度について述べてみた。

コークス壁のマイクロ硬度には, ビッカース ${ }^{99)}$ と又 一プ硬度 ${ }^{100}$ が測定されているが, 熱処理後室温で測定 した場合は，治金用コークスでは $1200^{\circ} \mathrm{C}$ 付近に250〜 $300 \mathrm{~kg} / \mathrm{mm}^{2}{ }^{100)}$, 石油コークスでは $900^{\circ} \mathrm{C} に 140 \mathrm{~kg} / \mathrm{mm}^{2}$ 101)の極大值が見られるが，高温下で測定した場合は， 硬度は温度と共に低下し, 常温で $300 \mathrm{~kg} / \mathrm{mm}^{2}$ レベルが $1100^{\circ} \mathrm{C}$ では200 $150 \mathrm{~kg} / \mathrm{mm}^{2}$ と半隇している ${ }^{102)}$ 。高温 から冷却しながら測定すると, 可逆線上に乗るるのも あるが最初の值の 6 割程度にしか回復しないサンプル るある ${ }^{102)}$ (図 9 参照)。なお、ヌープ硬度 $\left(H_{\mathrm{K}}\right)$ から 動的ヤング率 $(E)$ を求める式が提出されている。

$$
E=0.027 H_{\mathrm{K}} \times 10^{10} \text { dyne } / \mathrm{cm}^{2}
$$

(15)式は石炭で求めた式をそのままコークスに応用し たもので，Eは気孔率零の状態のものと考兄られる。 引張強度と気孔率の間には, 明瞭な関係 ${ }^{105}$ )が報告され ているが(図10参照) ${ }^{117)}$, 破壞強度 (両端をささえた試 片の長さの中央線上荷重をかけ，折り曲げ破壞の荷 重より求める) と気孔率の間の関係はバラッキが多い

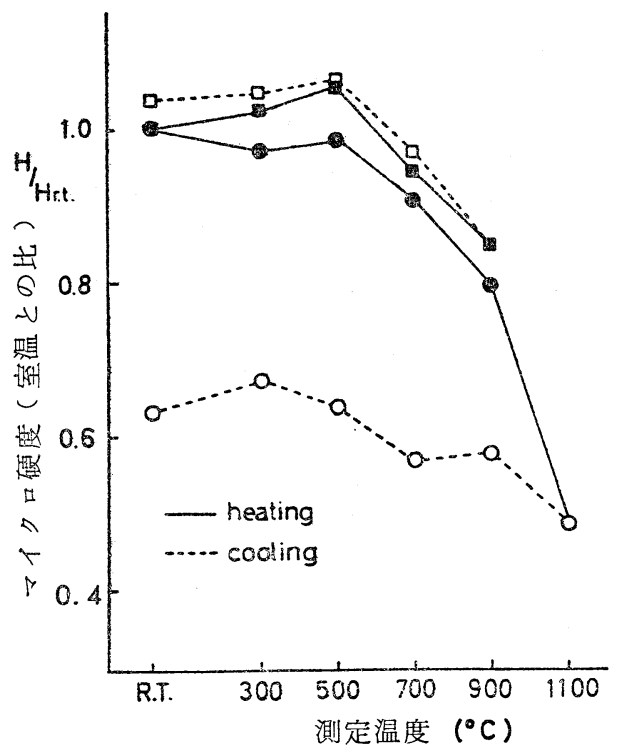

図 9 マイクロ硬度の温度依存性

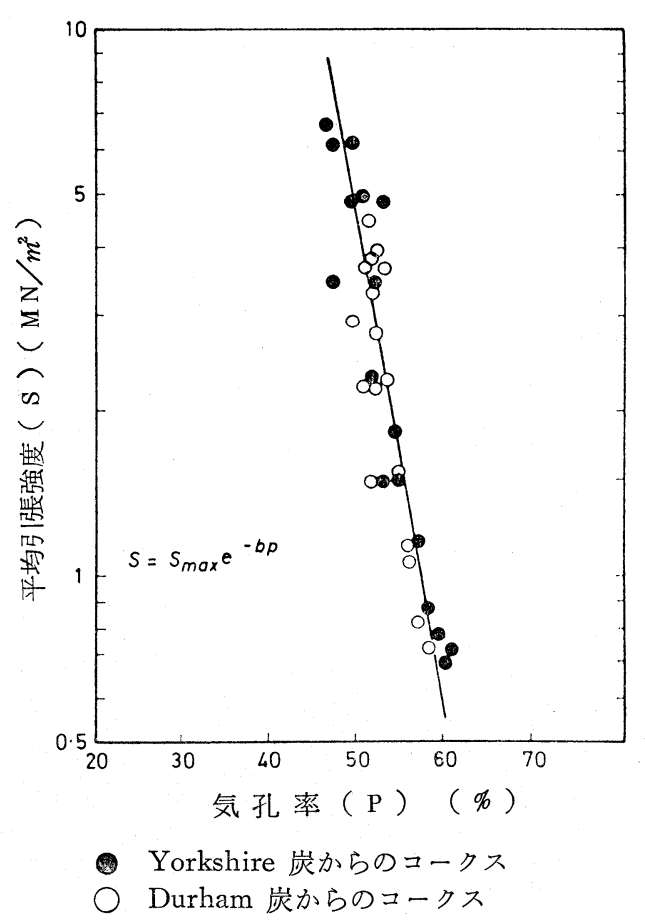

図 10 引張強度と氮孔率の関係

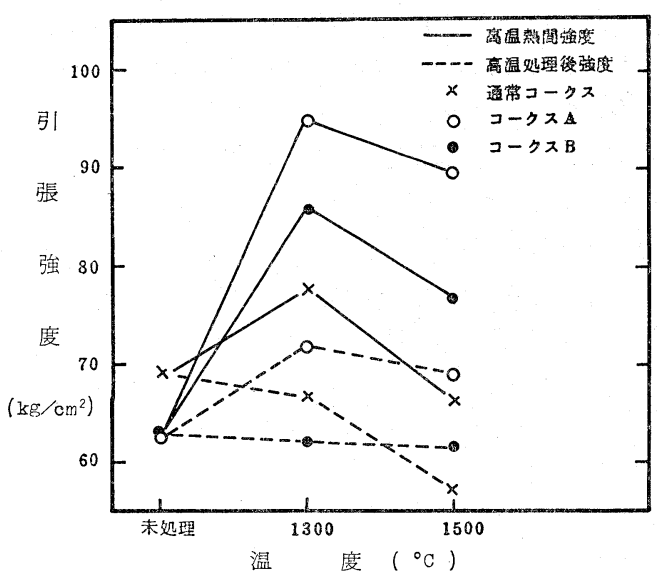

図 11 コークスの弓張強度の温度依存性

104)。この理由の一つに引張強度の繰返し数が 130 飞も の漂っている(106)ことがいえよう。高温下で引張強度を 測定した例では $1300^{\circ} \mathrm{C}$ では室温の強度よりも高い值 を示すが， $1500^{\circ} \mathrm{C} て ゙$ 測定すると室温の強度よりも低い

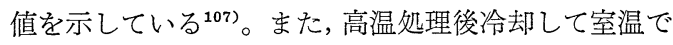
測定した引張強度はいずれる高温時で測定した值より る低くなっている ${ }^{107)}$ (図11参照)。この一見矛盾するマ イクロ硬度と引張強度の現象の差は, 次のような一つ 
表 1 熱間ドラム試験機

\begin{tabular}{|c|c|c|c|c|c|c|}
\hline & 1 & 2 & 3 & 4 & 5 & 6 \\
\hline 最高温度 ( $\left.{ }^{\circ} \mathrm{C}\right)$ & 1,000 & 1,000 & 900 & 1,000 & 1,500 & 1,500 \\
\hline ドラム材質 & （耐熱鋼） & インコネル600 & （耐熱鋼） & （耐熱鋼） & $\mathrm{SiC}-\mathrm{Si}_{3} \mathrm{~N}_{4}$ & $\mathrm{SiC}-\mathrm{Si}_{3} \mathrm{~N}_{4}$ \\
\hline ドラム内径 $(m m \dot{\phi})$ & 70 & 150 & 130 & 200 & 230 & 600 \\
\hline 長さ（mm) & 100 & 150 & 200 & 250 & 460 & 710 \\
\hline 回転速度 (rpm) & 100 & 150 & 50 & $40 \rightarrow 20$ & 25 & 20 \\
\hline 回転時間（min） & 30 & 40 & 40 & $60+15$ & 4 & 50 \\
\hline 回 転 数 $(\gamma)$ & 3,000 & 6,000 & 2,000 & 2,700 & 100 & 1,000 \\
\hline 試 料 量 (kg) & 0.015 & 0.15 & 0.20 & 0.10 & 2.5 & 5 \\
\hline " 粒度 (mm) & $15 \sim 20$ & $5.66 \sim 10$ & $25 \sim 30$ & $5 \sim 9.5$ & $\begin{array}{r}\quad 40 \sim 60 \mathrm{~mm} \\
\text { ans } 20 \sim 60 \mathrm{~g}\end{array}$ & $50 \sim 75$ \\
\hline 指＼cjkstart数 & $-3 \mathrm{~mm}$ & $+2.83 \mathrm{~mm}$ & $3 \mathrm{~mm}$ & +10.5 mesh & $10,20,30 \mathrm{~mm}$ & $25 \mathrm{~mm}$ \\
\hline 雾 囲 気 & $\mathrm{N}_{2}$ & $\mathrm{~N}_{2}$ & $\mathrm{~N}_{2}, 0.5 l / \mathrm{min}$ & $\mathrm{N}_{2}$ & $\mathrm{~N}_{2}$ & $\mathrm{~N}_{2}$ \\
\hline 加熱方法 & 気 & 気 & 電 気 & 電 & ガ & 電 \\
\hline 考 & $\begin{array}{l}\text { 鋼球 }(14 \mathrm{~mm} \phi) \\
14 \text { 装 } \\
\text { 入 }\end{array}$ & $\begin{array}{l}\text { 鋼球 }(19 \mathrm{~mm} \phi) \\
35 \text { ケを同時装 } \\
\text { 入 }\end{array}$ & $\begin{array}{l}\text { 八ネ } \\
5 \mathrm{~mm}) 3 \text { 枚 }\end{array}$ & $\begin{array}{l}\text { ボール } \\
(14 \mathrm{~mm} \phi) 20 \\
\text { ケを同時装入 }\end{array}$ & 八ネ 4 枚 & $\begin{array}{l}\text { 八ネ } \\
(30 \times 355 \mathrm{~mm}) \\
4 \text { 枚 }\end{array}$ \\
\hline 献（年） & $\begin{array}{l}1961 \\
(109)\end{array}$ & $\begin{array}{l}1967 \\
(110)\end{array}$ & $\begin{array}{l}1968 \\
(111)\end{array}$ & $\begin{array}{l}1968 \\
(112)\end{array}$ & $\begin{array}{l}1969 \\
(113)\end{array}$ & $\begin{array}{l}1976 \\
(114)\end{array}$ \\
\hline
\end{tabular}

の推論で理解されよう。即ち, $1300^{\circ} \mathrm{C}$ という乾留温度 の範囲内では，コークスは熱膨脤するためにマイクロ 硬度の低下を十分に補いむしろ引張強度は向上する。 しかし, 乾留温度以上になると, 収縮による稂が顕 在化するてめ引張強度は低下すると考光られる。熱処 理後冷却して室温で測定する場合は, 冷却過程の収縮 歪が吸収しきれず裂が発生するためであろう。その 外, この基質強度に類したものにマイクロ強度(MSI) がある。これ性代用特性値であり，鋼製のチューブに $1 \mathrm{~mm}$ 前後の粒径のコークスを鋼球とともに入れて, 回 転させ被破研度を見るものであるが，熱処理温度とと もに MSIは高くなっており ${ }^{100)}$, マイクロ硬度とは明 らかに異質のものである。岕る限定したサンプル内で は引張強度とマイクロ強度との間に正相関が認められ ている105)。

(熱 歪)

コークスを急激に高温に加熱すると、コークス塊内 に温度公眍ろ゙生じる。実際の高炉内でュークス塊表面 と中心部との温度差が大きくなるのは, シャフト上部 と羽口周辺であり, その值は $250 \sim 300^{\circ} \mathrm{C}$ 亿達すると推 定されている。(16)式を用いてコークス塊内湓生する 応力 $\sigma_{\mathrm{T}}$ が計算されているが, $100 \mathrm{~mm}$ のコークス塊で $30 \mathrm{~kg} / \mathrm{cm}^{2}$ 程度の徝が出ている ${ }^{108)}$ 。

$$
\sigma_{\mathrm{T}}=\beta E\left(\bar{t}-t_{\mathrm{X}}\right) /(1-\nu)
$$

但し $\nu:$ ポアソン比 $\beta$ : 熱膨脹率

$$
E: \text { ヤング率 } \bar{t}: \text { 平均温度 } t_{\mathrm{x}} \text { : 表面温度 }
$$

(ドラム強度)

コークスの機械的強度を工業的見地から把握するた めに, 従来から室温で回転させるドラム試験機が用い られてきた。塊コークスの熱的劣化を測定する場合 も，当然のようにドラム試験方式が検討されてきた。 各種の高温ドラム試駼機の一覧表を表 1 亿示したが,

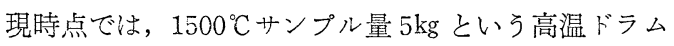
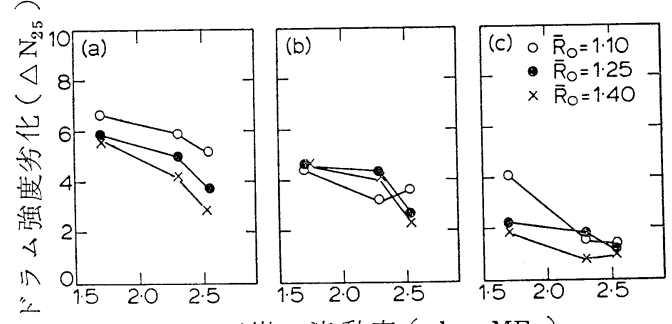

石炭の流動度 ( $\log \mathrm{MF}$ )

(a) $\mathrm{CO}_{2}$ 処理後 $1500^{\circ} \mathrm{C}$ ドラム

(b) $\mathrm{CO}_{2}$ 処理後室温ドラム

(c) $1500{ }^{\circ} \mathrm{C}$ ドラム

図 12 配合炭の流動度と石炭化度の 熱的劣化への影響 


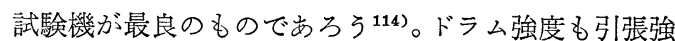
度と同様に $1300^{\circ} \mathrm{C}$ 付近から劣化が観察されている。ド ラム強度劣化の大きいコークスは, 難黒鉛化炭素であ るイナート質を多く含有していたり ${ }^{114)}$, 気孔率が高く 基質強度の弱いコークスを生成する低石炭化度炭を多 く配合したコークスであったり，あるいは，流動性の 低い石炭を原料としたものであることが明らかにされ ている115)。罒12にその一例を示した。

\section{5. あとがき}

高温に打けるコークスの物性変化について述べた が, 此重, 比熱, 熱伝導度, 熱膨脹, 耐圧強度, シャ ッター強度さらにはカーバイド化合物形成に打ける反 応性等紙面の都合で割愛したものが少なくない。単な る物性の羅列だけでなく，物性が変化する要因につい て極力記述したつもりであるが，最初にも触れたよう に定量的な論旨の展開は難つかしい。なお， $\mathrm{CO}_{2}$ 反応 後強度が測定されだしたので, コークスの物理的性状 と化学的性状の結びつきがより鮮明になってくるだろ うし, コークスの機械的強度の表示にも進歩が期待さ れよう。また, 整理不十分のため文中説明不足や理解 乙難い箇所が多いことを深く打詑びします。

\section{文献}

1）本田英昌, 石炭科学の進歩第 1 集，135（1956）白 垔書房

2）井上勝也，石炭科学の進歩第 2 集，268（1956）白 要書房

3) F. Goodarzi and D. G. Murchison, Fuel, 51,332 (1972)

4) F. Goodarzi and D. G. Murchison, ibid., 52, 164 (1973)

5) M.Inagaki, K. Horii and S. Naka, Carbon, 13, 97 (1975)

6) E.Fitzer and S. Weisenburger, ibid., 14, 195 (1976)

7) H.N.Murty, D. L. Beiderman and A. Heintz, Fuel, 57, 442 (1978)

8) A. C̄ya and S.Ōtani, Carbon, 14, 191 (1976)

9) R.E. Franklin Brennstott chemie., 34, 357 (1953)

10) H. E. Blayden, J. Gibson and H. L. RiLey Presented at a conference on the Ultra-fine stucture of coals and cokes, BCURA, London (1943)

11）水島三知，材料，14（146）861（1965）

12) E. Fitzer and S. Weisenburger, Carbon, 12, 657
(1974)

13）木村英雄, 白石稔, 小泉哲人, コークスサーキュ ラー, 16, (3) 91 (1967)

14) J.P. Rouchy and L. Gatineau, Carbon, 14, 97 (1976)

15) R.E.Franklin, Proc. Roy. Soc. London A209, 196 (1951)

16) K. Kamiya and K. Suzuki, Carbon, 13, 317 (1975)

17) K. Kamiya, M.Inagaki, M. Mizutani and T. Noda Bull. Chem. Soc. Japan, 41, 2169 (1968)

18) H.Sato, H.Ohashi and N.Setaka, Am. Ceram. Bull. 53, 261 (1973)

19) H. Takahashi, H. Kuroda and H. Akamatsu Carbon, 2, 432 (1965)

20) C. R. Houska and B.E. Warren, J. Appl. Phys. 25, 1503 (1954)

21）川名善男, 石炭科学の進歩第 2 集, $24 \mathrm{p}$ (1956) 白巠書房

22）飯島保雄, 宮津隆, 荒井均, コークス技術年報, ユークスシリーズ, 11, 50 (1961)

23）山辺潔, 高橋浩, 学振 117 委, 117-155-A-4 (1979)

24) M.F. Kessler and L. Dockalová, BrennstoffChemie, 46, (6) 172 (1965)

25）堀川秀一, 石炭科学の進歩第 1 集, 383 (1956) 白 亜畫房

26) V.V.Kazmina, Coke u Chem USSR, 1971 (6) 25

27) M.K.Hussein, S.Z.El-tawil and M.A.Rabah, J, Inst. Fuel, 1976, 49, 139

28) R.E. Leibouich, A.I.Bublik, V.F. Shelest and S. K. Shelkov, Coke u Chem USSR 1969 (11) 17

29) R. D. Ridley, Amer. Chem. Soc., 1970, 14, 101

30) H. Abramowitz, Carbon, 14, 84 (1976)

31）畑 俊彦, 河野吉久, 鉄と鋼, 64, (12), 1671 (1978)

32）吉永真弓, 一伊達稔, 松野二三朗, 久保敏彦, 鉄 と鋼，63，S520 (19L4)

33）吉永真弓, 一伊達稳, 久保敏彦, 鉄と鋼, 67, 5511, (1978)

34）鈴木朢一, 安藤遼, 吉越英之, 山岡洋次郎, 長岡 清四郎，鉄と鋼，61，(13）2775（1975）

35）金子恭二郎，佐野信雄，大塚一，前田正史，松下 
幸雄, 鉄と鋼, 64, S 89 (1978)

36) A.P.Bronshtein M.A. Tseitlin and Yu.

G. Voronov Coke u Chem USSR, 1967 (4) 14

37）豊田貞治，資源技術試験報告74号 A-19（1969）

38) 坂輪光弘, 小島鴻次郎, 第 4 回炭素材料学会 (1977)

39) N. Berkowitz, P.A. Cavell and R.M.Elofson, Fuel, 40, 279 (1961)

40) F. Tuinstra and J. L. Koenig, J. Chem. Phys., 53, 1126 (1970)

41) M.Nakamizo, R. Kammereck and P.L.Walker. Jr, Carbon, 12, 259 (1974)

42) M. Nakamizo, M. Inagaki and Y.Hishiyama Carbon, 15, 295, (1977)

43）松山英太郎，日本金属学会会報，1964（8）383

44) 福岡元次, 堀部富雄, 中井祐三, コークスの研究 コークスシリーズ， 6，36 (1956)

45）吉永真弓，一伊達稔，久保敏彦，伊藤伸夫，鉄々 鋼, 63，S521 (1977)

46) E.M.Taits, N.K. Ermolaeva and Yu. S. Niko -laev, Coke u Chem USSR, 1970 (2) 19

47) Yu. L. Tikhomirov, Yu. B. Tyutyunnikov, A. V. Agar kova and N. I. Tuchina, Coke u Chem USSR, 1972 (5) 21

48) A.S. Parker and H. C. Hottel, Ind. Eng. Chem. 28, 1334 (1936)

49）森山昭, 谷口平光, 吉田幸生, 鉄と鋼, 63, 201 (1977)

50) M. Rossberg and E. Wicke, Chem. Ing. Tech., 28, 181 (1956)

51) I. W.Smith, Fuel, 57, 409 (1978)

52) N. Schapiro and R.J.Gray, Blast Fvr. St. p 1. 1963 (4) 273

53）樫野泰三, 和佐昭, 横山徹, 松井稔, 燃協誌, 48 , 103 (1969)

54) M. Besting, R. R. Hartwell and H.C.Wilkinson, Fuel, 56, 319 (1977)

55）角南好彦，小川真資，鉄と鋼，63，（4）S80 (1977)

56）杉村秀彦, 熊谷光照, 木村英雄, 燃協誌, 49,744 , (1970)

57）村上昭三，原義明，石川功，コークスサーキュラ -, 23, (2) 82 (1974)

58) L. D. Miller, R. W. Bouman and M.C.Chang, Blast. Fur. St. p 1., 1965 (5) 381
59）斉藤安俊，高温学会誌，2，(5）262（1976）

60）山口德二，奥原捷晃，古井健夫，コークスサーキ ュラー, 23, (4) 261 (1974)

61）奥山泰男，柳内衛，宮津隆，コークスサーキュラ - , 28, (2) 130 (1979)

62) B. P.Jalan and Y.K. Rao, Carbon, 16, 175 (1977)

63）小林三郎，大森康男，鉄と鋼，64，S 510 (1978）

64) J.W.Patrick and F.H. Shaw, Fuel, 51, (1) 69 (1972)

65) E. T. Turgdogan and J. V. Vinters, Carbon, 8, 39 (1970)

66) S.Ergun, J. Phys. Chem, 60, 480 (1956)

67) H.J.Grabke, Ber, Bunsenges, Phys. Chem., 70, 664 (1966)

68) H. D. Beyer, V. Pückoff and K.H. Ulrich, Arch Eisen-hütten, 43, 597 (1972)

69) J.Gasby, F. J.Long, P. Sleightholm and K.W. Sykes, Proc. Roy. Soc., A193, 357 (1948)

70) H. Hedden and A Löve, Carbon 5, 339 (1967)

71）近藤真一，原行明，土屋勝，鉄と鋼， 60, S 33 (1974)

72）田口整司，岡部俠児，川鉄技報，2，358（1970）

73) W.Peters and H.Jüntgen, Brennstoff-Chem., 46, (6) 175 (1965)

74）福山辰夫, 宮津隆, 奥山泰男, 木村英雄, 白石稔, 然協誌, 47, 607 (1968)

75) K.I.Syskov and V.M.Sergeer, Koks i Khimiya, No. 4, 12 (1977)

76）宮坂尚親，近藤真一，鉄と銅，54，1427（1968）

77) C. Offroy and M. Olette, CESSID internat report 76-13 (1976)

78) V.K.Kornev and S. V.Shavrin, Steel in the USSR. 96 (1971)

79）松尾寛二，堀昭二，池田茂，炭素，79，118（1974）

80) K. J.Hüttinger and U.Rosenblatt, Carbon, 14, 267 (1976)

81) E. Fitzer and S. Weisenburger, Carbon, 14, 323 (1976)

82) A.A. Agroskin and I. E. Svyatets, Coke u Chem., 1967 (3) 28

83) C. E. Marshall, Fuel, 24, 120 (1945)

84) J. W. Patrick, M.J. Reynolds and F.H. Shaw, Carbon, 1975, 13, 509

85) G. H. Taylor, Fuel, 40, 465 (1961) 
86) N.A. Vasyutinskii and Yu. I.Ryseva, Coke u Chem. USSR. 1965 (1) 25

87) M.Inagaki, Y.Tamai, S.Naka and K.Kamiya, Carbon, 12, 639 (1974)

88）真田雄三, コークスサーキュラー，23，（3） 180 (1974)

89) M. Inagaki, M. Ishihara and S. Naka, Carbon, 14, 88 (1976)

90) R. R. Adair, E. H. Boult and H. Marsh, Fuel, 51, 57 (1972)

91) H. Marsh and T.Siemieniewska, Fuel, 44, 355 (1965)

92) T.G. Lamond. Ph D Thesis, Univ. of Durham (1962)

93) K.A.Kini, Fuel, 43, 173 (1964)

94) A.I. Voloshin, L. P. Semisalov, E. B. Baskina and O.A.Nesterenko, Coke u Chem USSR, 1967 (10) 20

95) Y. Toba, N. Yuki and S. Toyoda, Carbon, 10, 13 (1972)

96) D.G. Murchison, Analytical Methods for Coal and Coal Product (II), p 415 (1978) Published Academic Press.

97) D. Chandra, Fuel, 43, 171 (1964)

98) A.J.R. Bennett, Fuel, 47, 51 (1968)

99) M. B.Alpern, C. R. Acad. Sci, Paris, 242, 653 (1956)

100) H. Honda and Y.Sanada,Fuel, 35, 4.03 (1956)

101) V. V.Zelenina and O.P. Gorokh, Coke $u$ Chem USSR, 1973 (2) 23

102）白石稔, 熊井順二郎, 木村英雄, 吉田雄次, 燃 協誌, 46, 483 (1967)

103）宮川亜夫，藤島一郎，燃協誌，54，983 (1975)

104）井上勝也, 谷秀夫, 燃協誌, 33, 587 (1954)

105）川崎製鉄，第13回コークス分科会（1976）八幡

106) J.W.Patrick and A.E.Stacey, Fuel, 51, 206
(1972)

107）住友金属，第13回コークス分科会（1976）八幡

108) Yu. Ya. Filonenko, V.N.Sharipov and A.V. Kurbatov, Koks i Khimiya, No.8, 20 (1976)

109) N. M.Smolyaninova, A. A. Kaplin and L. M. Vasileva, Coke u Chem. USSR, 1961 (5) 24

110）宮津隆, 小泉哲人, 福山辰夫, 森山幸治, 第43回 コークス特別会, 東京, (1967)

111）中谷文忠, 角南好彦, 第 45 回コークス特別会, 東京 (1968)

112）松阪治, 森幹夫, 池尻平三郎, コークスサーキュ ラー, 17, (2), 61 (1968)

113) K. Bradshaw and H.C. Wilkinson, J. the Institute of Fuel, 1969 (3) 112

114）宮津隆，柳内衛，室屋正広，奥山泰男，鉄之鋼， 62, S 27 (1976)

115) T.Miyazu, Y. Okuyama, T.Fukushima, M. Yanagiuchi and T. Izawa, Proceeding of Coal, Coke and the blastfurnace 66, Middlesbrough, the Metal Society (1977)

116) M.P. Whittaker, F.C. Miller and H. C.Fritz, Ind.Eng. Chem. Prod. Res. Develop., 9, 187 (1970)

117) J.W. Patrick and A.E. Stacey, Fuel, 54, 256 (1975)

118) R. Brunger, Coke in lron making I.S.I Publication, 127 p 114 (1969)

119）中村正和, 杉山喬, 鵜野建夫, 原行明, 近藤真 一，鉄之鋼，63，（1）28（1977）

120）奥山泰男, 柳内衛, 宮津隆, コークスサーキュラ 一, 28, 130 (1979)

121）小林三郎，大森康男，鉄と鋼，63，1081（1977）

122）板谷宏, 福武剛, 岡部俠览, 長井保, 鉄と鋼, 62, (5) 472 (1976)

123）原行明，中村正和，小島鴻次郎，製鉄研究，295, 12610 (1978) 


\title{
The Properties of Coke at High Temperature
}

\author{
Yasuo OKUYAMA
}

\author{
(Nippon Kokan K.K. Technical Research Center)
}

SYNOPSIS : - The degree of graphitization of coke is increased at higher temperature than the carbonization temperature. As the heat treatment temperature (H.T.T.) increase, the three dimension crosslinkage of layers develope to the second dimensional graphite like net structures (so called the turbostratic ones) and finally the graphite crystal structure is completed. The physical and chemical properties of coke is reviewed in the coures of graphitization at high temperature :

1) The most properties of coke is highly dependent on the H.T.T.

2) The higher H.T.T. cause the reduction of hetero atoms (S.N.P.H) making coke inert but the ash components behave sometimes as catalysts to increase the reactivity of coke at higher than $1700^{\circ} \mathrm{C}$.

3) The electromagnetic properties of coke show clearly the progress of the graphitization when the H.T.T. increasing.

4) The mechanical properties of coke: The intrinsic strength, determined with such as knoop hardness, is reduced as the higher temperature. On the other hand, the structural strength is high below the carbonization temperature and over the carbonization temperature it become weak mainly due to the shrinkage. 